\title{
A review and meta-analysis of growth and life-history traits of a declining European freshwater fish, crucian carp Carassius carassius
}

\author{
ALI SERHAN TARKAN ${ }^{\mathrm{a}}$, DAVID ALMEIDA ${ }^{\mathrm{b}, \mathrm{c}, \mathrm{d}}$, MICHAEL J. GODARD ${ }^{\mathrm{b}}$, ÖZCAN GAYGUSUZ ${ }^{\mathrm{e}}$, MARK RYLANDS ${ }^{\mathrm{f}}$, \\ CARL D. SAYER ${ }^{\mathrm{g}}$, GRZEGORZ ZIĘBA ${ }^{\mathrm{b}, \mathrm{h},}$ and GORDON H. COPP ${ }^{\mathrm{b}, \mathrm{c}, \mathrm{d}, *}$ \\ ${ }^{a}$ Muğla Sitkı Koçman Üniversitesi, Su Ürunleri Fakültesi, Kötekli, Muğla, Turkey \\ ${ }^{\mathrm{b}}$ Salmon and Freshwater Team, Cefas, Lowestoft, Suffolk, UK \\ ${ }^{\mathrm{c} C e n t r e ~ f o r ~ C o n s e r v a t i o n ~ E c o l o g y ~ a n d ~ E n v i r o n m e n t a l ~ C h a n g e, ~ B o u r n e m o u t h ~ U n i v e r s i t y, ~ P o o l e, ~ D o r s e t, ~ U K ~}$ \\ ${ }^{\mathrm{d}}$ Environmental Life Sciences Graduate Program, Trent University, Peterborough, Ontario, Canada \\ e İstanbul University, Faculty of Fisheries, Ordu Cad, Laleli, İstanbul, Turkey \\ ${ }^{\mathrm{f}}$ Riverine Ecological Solutions Limited (RESL), Watton, Norfolk, UK \\ ${ }^{\mathrm{g}}$ Environmental Change Research Centre, Department of Geography, University College London, London, UK \\ ${ }^{\mathrm{h}}$ Department of Ecology and Vertebrate Zoology, University of Łódź, Banacha 12/16, 90-237 Lódź, Poland
}

\begin{abstract}
1. In response to reported declines in crucian carp Carassius carassius across Europe, studies of the status and population biology of the species in England led to Biodiversity Action Plan priority designation in the eastern county of Norfolk.

2. In light of new data on crucian carp populations in eastern England (counties of Essex, Hertfordshire and Norfolk), a comprehensive review of available information throughout its native and introduced European range was undertaken to assess the growth and reproduction at a broader scale, thus contributing to conservation and management strategies at a country scale in the UK.

3. For all populations, mean sex ratio was 1:1, back-calculated total length (TL) ranged from 19 to $334 \mathrm{~mm}$, and maximum age was 13 years. Growth and body condition varied greatly across Europe. Growth trajectories in England, Russia and Poland were significantly faster than in Finland. Within England, growth index was lower in Hertfordshire than in Essex and Norfolk, and Fulton condition (plumpness) index was higher in Essex than in Norfolk.

4. Reproductive traits varied greatly both in males and females, with age at maturity ranging from 1.5 to 5 years, and with the shortest life spans observed in England. Length at maturity was usually at a lower TL in males than females (except in Essex populations). Female age at maturity decreased significantly with juvenile growth, which was defined as TL at age 2, the age above which females in most populations achieved maturity.

5. Predicted temperature rise (i.e. under a climate change scenario) may benefit crucian carp growth, as predicted for related competitive invaders (e.g. goldfish Carassius auratus). From a conservation perspective, suggested management strategies include reducing populations of non-native fishes, implementing measures of habitat restoration and re-stocking rehabilitated ponds from 'source areas', i.e. those containing crucian carp populations in good status.
\end{abstract}

Received 8 October 2014; Revised 23 April 2015; Accepted 2 June 2015 *Correspondence to: G. H. Copp, Salmon \& Freshwater Team, Cefas, Pakefield Road, Lowestoft, Suffolk NR33 OHT, U.K. E-mail: gordon.
copp@cefas.co.uk

This article is published with the permission of the Controller of HMSO and the Queen's Printer for Scotland. 
KEY WORDS: length and age at maturity; geographical comparisons; body condition; threatened species; aquatic conservation; freshwater fish

\section{INTRODUCTION}

Crucian carp Carassius carassius is a species native to north-western and central Europe (http://www.fishbase.org/summary/270), where it is a characteristic fish of ponds, small lakes and river floodplains (Marlborough, 1966; Holopainen et al., 1997; Szczerbowski et al., 1997; Wheeler, 2000; Keresztessy et al., 2013). In England, which is the western limit of its range, crucian carp is found mainly in ponds and historically is said to be 'a fish of the English plain', with its main areas of distribution being the regions Thames and Anglia (Marlborough, 1966). This cryptic cyprinid has no great commercial or sport value and, consequently, the species is known to anglers but mostly unknown to the general public. However, from a scientific perspective, crucian carp has been the subject of extensive research in Finland during the 1980s and 1990s (Holopainen and Pitkänen, 1985; Holopainen and Ikari, 1992). In England, this fish species began to attract increased scientific interest (Wheeler, 2000; Copp et al., 2008a, b; Tarkan et al., 2009, 2011) after pharyngeal bones from a Roman archaeological site in Southwark (London) were identified as crucian carp by A.C. Wheeler (Jones, 1978; Newdick, 1979). Crucian carp was subsequently considered by some as a species native to the UK (Wheeler, 2000) but not by others (Maitland, 2004), and genetic studies of crucian carp are currently under way to address this issue.

Despite the crucian carp still being common in parts of northern Europe, where their populations show good conservation status, this species has been in decline throughout most of its native range (Steiner, 1988; Schwevers et al., 1999; Navodaru et al., 2002). The most recent threat to the northern populations is the expansion of its invasive congener, gibel carp Carassius gibelio, from the southern to northern Baltic states (Vetemaa et al., 2005; Wouters et al., 2012; Deinhardt, 2013). In England, a steep decline in crucian carp populations has been also observed (Sayer et al., 2011), with a reduced occurrence of $\approx 75 \%$ in the county of Norfolk since the 1970s-1980s (Sayer et al., 2011). This has led to this fish being designated as a Biodiversity Action Plan priority species in Norfolk (Copp and Sayer, 2010), its first formal conservation designation in the UK. Thus, several studies have focused on determining both biotic and abiotic causes of the strong decline of the species (Hänfling et al., 2005; Copp et al., 2010; Sayer et al., 2011).

Effective conservation requires a good knowledge of the environmental biology of a species, in particular those traits that demonstrate considerable plasticity in response to local environmental conditions (Mann, 1991), such as growth and reproduction in crucian carp (Holopainen et al., 1988; Szczerbowski et al., 1997; Copp et al., 2008a, b; Tarkan et al., 2009, 2011). At the local scale, in pond populations in which crucian carp reproduction is delayed and/or where growth rate and body condition are low, habitat rehabilitation efforts may be appropriate to facilitate revitalization of the existing populations. Conversely, ponds containing good stocks of crucian carp can serve as 'source areas' for the re-stocking of derelict ponds that have been rehabilitated. This approach has been used successfully for pond conservation elsewhere in Europe (Oertli et al., 2005; Rannap et al., 2009) and provides a potential model for the conservation of native crucian carp populations. To adopt this approach, an understanding of European-scale variation of crucian carp population traits is required to provide the context for country-scale conservation action, e.g. in the UK.

Consequently, the aims of the present study were to increase the information base currently available for crucian carp growth and life-history traits and to assess the geographical and latitudinal variations (effectively at latitudes $>50^{\circ}$ ) within this wider European context. The specific objectives were: (1) 
to complete a comprehensive re-examination of the literature to identify previously undiscovered data on the species (e.g. 'grey literature'); (2) to collect new population data (length at age, growth index, body condition, length and age at maturity, sex-ratio) in the most western extent of the European range of the species, the East of England; (3) to test for a causal relationship between juvenile growth and age at maturity, which has been found in other fish species to be influenced both by population level and geographical factors (reviewed in Fox, 1994); (4) to test for geographical patterns (e.g. latitudinal clines) in this larger data set on crucian carp populations; and (5) to suggest management and conservation measures for crucian carp populations in England.

\section{MATERIALS AND METHODS}

\section{Data collection and study areas}

Data on crucian carp populations in England and continental Europe were acquired from previous studies, as well as through bibliographic searches that included both published and grey literature. Descriptions of the study sites in Finland, Poland and Russia are provided in the original sources (Table 1). New data on crucian carp populations in England were derived from recent (Sayer et al., 2011) and new sampling campaigns, encompassing 24 ponds in three eastern counties (Essex, Hertfordshire, Norfolk). Annual rainfall across the study region ranges from $600-950 \mathrm{~mm}$ and peaks in autumn (180-270 mm), with mean annual temperatures ranging from $9.0-10.5^{\circ} \mathrm{C}$. Potential predators of crucian carp in England are great grey heron Ardea cinerea, great cormorant Phalacrocorax carbo (Copp et al., 2008b), Eurasian otter Lutra lutra (Almeida et al., 2013), and in some cases introduced northern pike Esox lucius were often found to have exterminated all other fish species (Copp et al., 2005; Sayer et al., 2011). These piscivorous species are widely distributed across the study ponds in England.

Although most ponds in England have their origins as livestock watering holes, monastic fish ponds, marl pits, and blacksmith ponds, those that remain (i.e. have not been filled in) have succumbed to natural ecosystem processes, including terrestrialization, and now are managed for their disproportionately high contribution to aquatic biodiversity (Williams et al., 2003; Copp et al., 2008b) or for their amenity value (e.g. angling). The study ponds in Hertfordshire and Norfolk are located in rural, agricultural areas, whereas the Essex ponds are found within Epping Forest (see Figure 1 in Tarkan et al., 2009 and additional details in Copp et al., 2005). The latter is a conservation area consisting of deciduous woodland and acid grassland to the north of London in which ponds are the subject of management for aquatic conservation (Conservators of Epping Forest, 2002). The location and character of Bayfordbury Lake in Hertfordshire $(\approx 0.8 \mathrm{ha})$, which is managed specifically for the conservation of crucian carp and other aquatic species, are described elsewhere (Copp et al., 2008a, b). The other two Hertfordshire ponds (Half Oak Pond, Search Light Pond) are located within the grounds of Hatfield House, a large country estate. Half Oak Pond (Lat. 51.747518, Long. -0.202800 ; area $\approx 0.3$ ha; mean depth $\approx 0.7 \mathrm{~m}$ ) is located in a wooded, inaccessible area, whereas Search Light Pond (Lat. 51.745585, Long. -0.191902 ; area $\approx 0.1$ ha; mean depth $\approx 0.6 \mathrm{~m}$ ) is located next to a country lane that passes through an area consisting of woods, fields and a few houses.

All of the study ponds in Norfolk are located in a low-lying, agricultural area of north Norfolk except Rocklands Mere. The ponds are in general shallow $(<2 \mathrm{~m})$, small $(<0.1 \mathrm{ha})$ and situated within arable or pasture land although a few of the ponds are found in mixed deciduous and coniferous woodland. Further details of the ponds are given in Sayer et al. (2011). Rocklands Mere (Lat. 52.544480 , Long. 0.928864; area $\approx 0.5$ ha; water depth $=0.8-2.1 \mathrm{~m}$ ) is a commercial fishery located in south Norfolk within an arable landscape, situated on an underlying bar of riverine clay and floodplain sand and gravel deposits. The mere was excavated in 2001 from this former peat extraction area, exploited during the early 1940s, which was encouraged to succeed to wet woodland as part of the historic Woodland Grant Scheme 3 owing to its poor suitability for arable production. 
Table 1. Latitude (Lat.) in ${ }^{\circ} \mathrm{N}$ of study ponds and water bodies elsewhere (L. = Lake; P. = Pond), back-calculated total lengths (TL) at age, growth index (GI), Fulton's condition factor $(K)$, mean TL at maturity $\left(\mathrm{L}_{\mathrm{M}}\right)$, mean age at maturity $\left(\mathrm{A}_{\mathrm{M}}\right)$ and sex ratio (males $\div$ females) of crucian carp populations in England and continental Europe. Norfolk pond details and locations given in Sayer et al. (2011). PL = Poland, RU = Russia, FIN = Finland

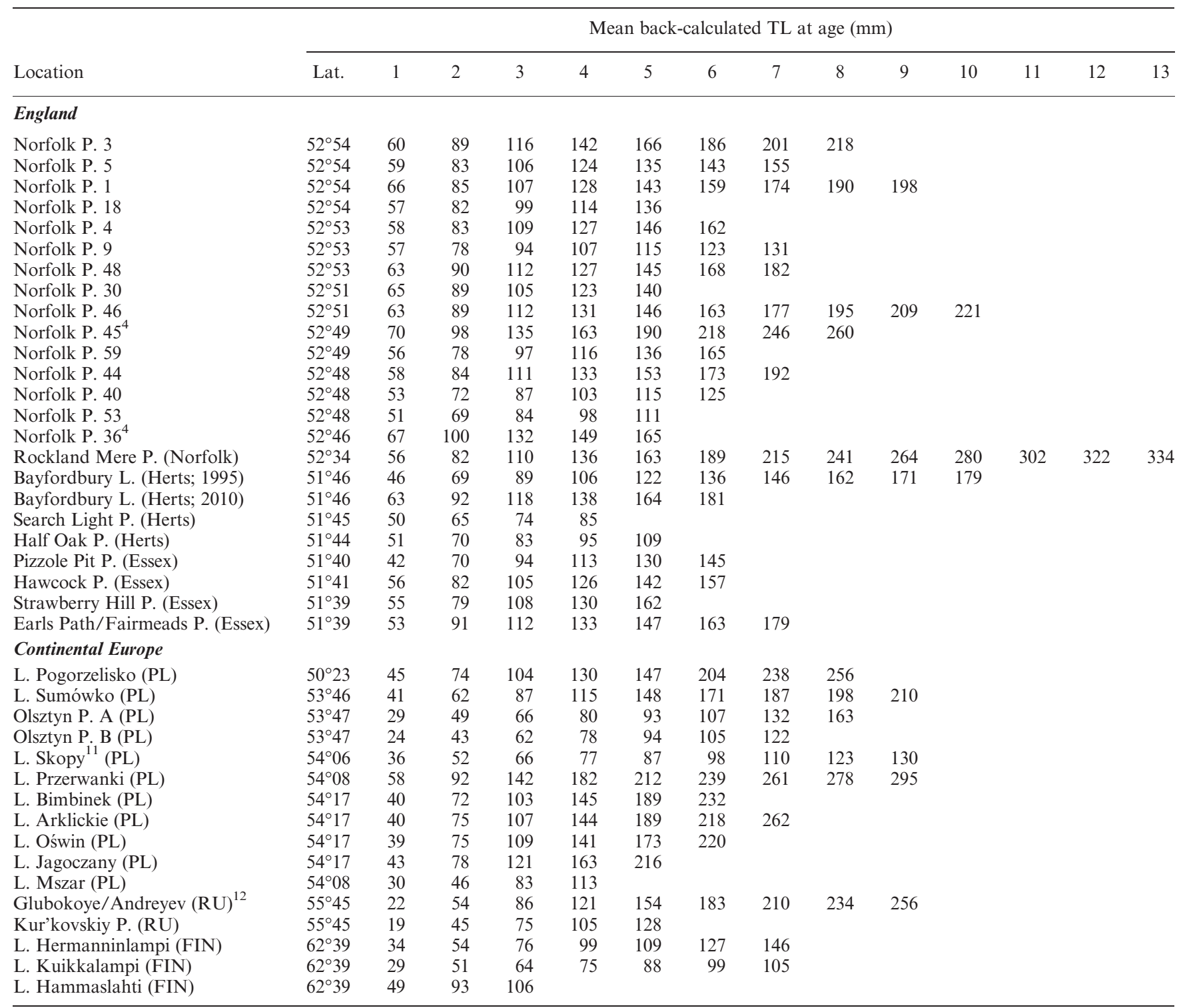

${ }^{1}$ No specimen of age 1 , with $100 \%$ matures observed at age $2 .{ }^{2}$ No specimens $<120 \mathrm{~mm}$ TL (males) or $<130 \mathrm{~mm}$ TL (females), with $100 \%$ matures observed at 120-129 and 130-139 mm TL, respectively. ${ }^{3}$ No females of age $<6$ years and no males of age $<5$ were captured, and $100 \%$ of the age 6 fish were mature. ${ }^{4}$ Back-calculated lengths of Jack's Pit and Salle Patch were derived from only one specimen for each population. ${ }^{5}$ No specimen $<60 \mathrm{~mm} \mathrm{TL}$, with 100\% matures observed at 60-69 mm TL. ${ }^{6}$ Fulton's value in SL (from Copp et al., 2008b) for 1995 converted to TL using conversion formula in Froese (2006). ${ }^{7}$ From Tarkan et al. (2009): no fish of age 0 or 1 were captured, thus AaM value assumes $50 \%$ of age 1 fish were mature (i.e. the mean of the estimates when age 1 fish are at $0 \%$ and at $100 \%$ mature, respectively). ${ }^{8}$ Sex ratio (calculated from original data) deviated significantly $\left(\chi^{2}=11.31 ; P<0.001\right)$ from unity. ${ }^{9}$ No specimens of age 2 , with $89 \%$ mature females and $100 \%$ mature males observed at age 3. ${ }^{10}$ No specimens of $<70 \mathrm{~mm}$ TL, with $100 \%$ matures observed at $70-79 \mathrm{~mm}$ TL. ${ }^{11}$ Data for female fish only, latitude given for nearest known town. ${ }^{12}$ Original source provides combined values for Lake Glubokoye and Andreyev Pond.

\section{Field sampling and laboratory analysis}

Field sampling in England was carried out in spring (i.e. just before spawning) between 2009 and 2012. Crucian carp were collected using double-ended fyke nets, which were set overnight and harvested in the morning. Electrofishing (generator-powered DC unit) was used in ponds too shallow for fyke nets to be used, or as a complement to fyke nets 
Table 1. (Continued)

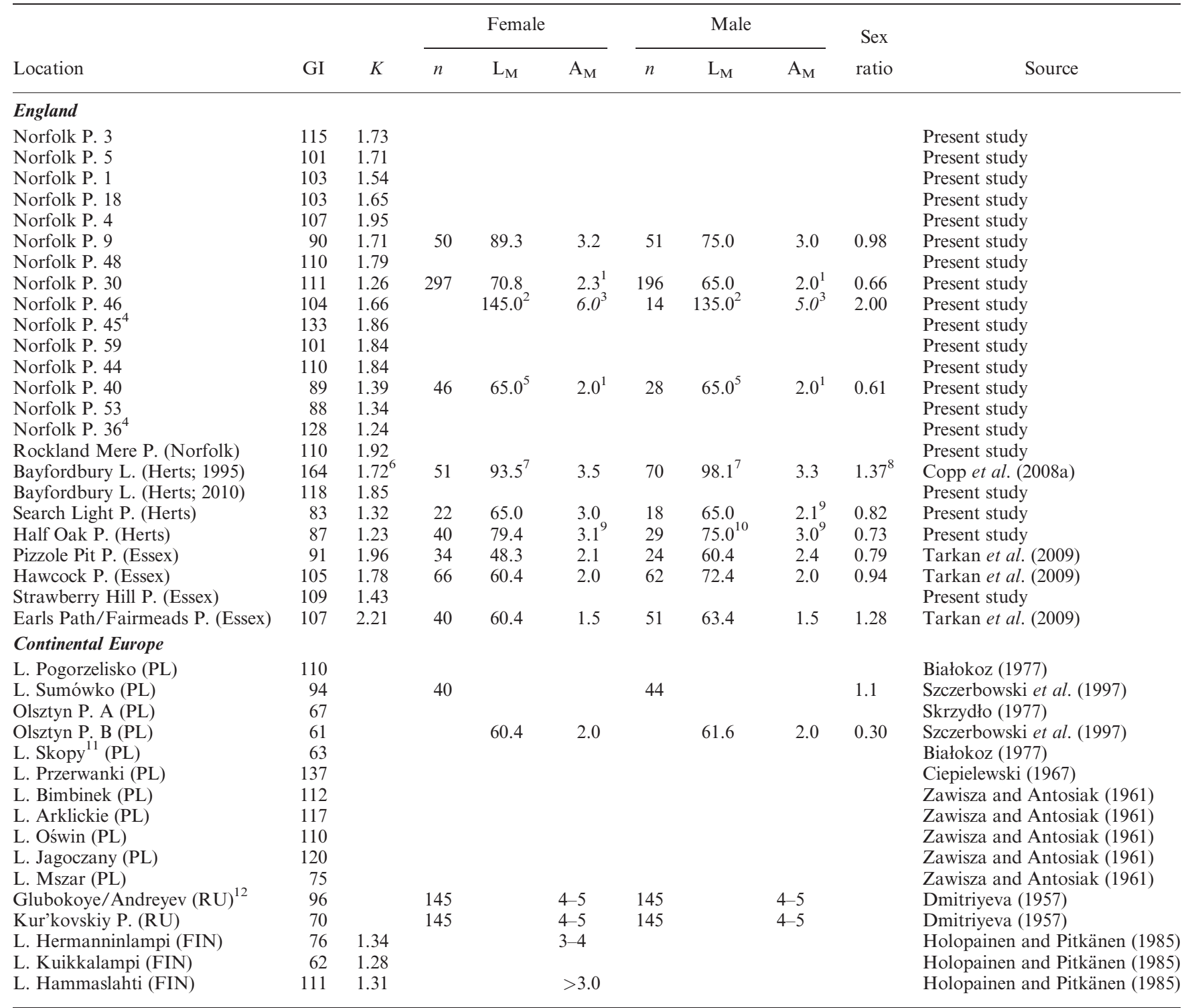

when few crucian carp were captured in the nets. To assess age, growth and body condition, the fish were measured for total length (TL) to the nearest millimetre and weighed to the nearest $0.1 \mathrm{~g}$. Scale samples were taken from the area between the lateral line and dorsal fin for each specimen in situ, with all fish returned to the water except in cases where sufficient numbers (i.e. $>50$ individuals) of crucian carp were captured. In this case, a sub-sample was taken for laboratory analysis of reproductive traits without adversely affecting the population. The retained specimens were killed with an overdose of 2-phenoxyethanol, immersed in a slurry of iced water (a procedure permitted under UK. Home Office project licence) and transported to the laboratory.

In the laboratory, gonads were examined to determine sex, classifying females with unrecognizable or non-yolked eggs as immature and those with yolked eggs as mature. Age was determined by 


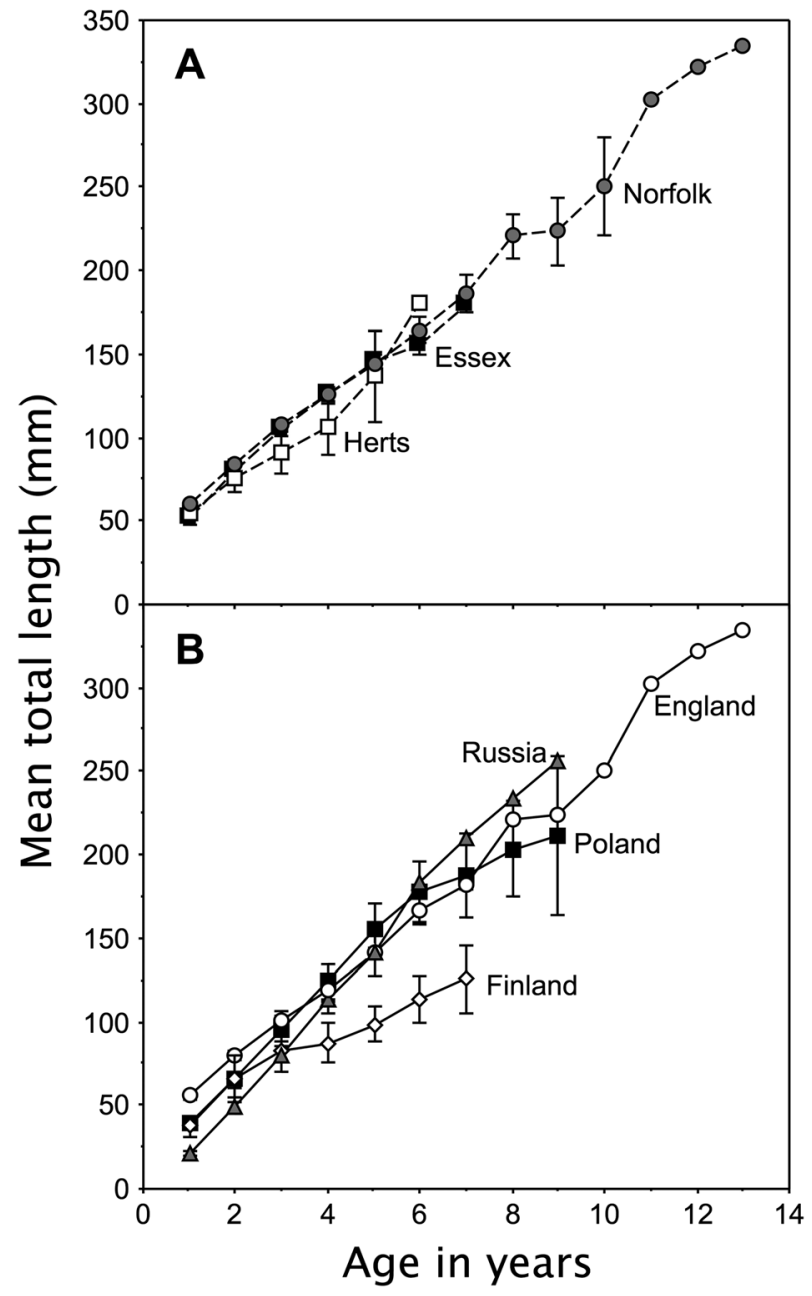

Figure 1. Mean back-calculated total length at age (with SE bars) of crucian carp Carssius carassius populations in (A) the east of England (by county: Norfolk, Hertfordshire and Essex) and (B) by country.

counting true annuli after Steinmetz and Müller (1991) and (Vilizzi et al., 2013) from acetate impressions of scales, read on a micro-projector (magnification: 48×). As in Tarkan et al. (2009), age determinations were undertaken independently by two readers, and when the interpretations were different an additional reading was made. If the disagreement continued, then the sample was excluded from further analysis - this occurred in $<5 \%$ of all scale samples. As the validity of age estimates was successfully accomplished in several previous studies on crucian carp in the UK including some populations currently studied (Tarkan et al., 2009, 2011; Copp et al., 2010), it was not repeated in the present study. The total scale radius and the radius of annual increments were measured from the focus to the posterior edge along the antero-posterior axis.

\section{Data analyses}

Non-linear and linear equations were fitted to determine which model best described the relationship between body length and scale radius (Bagenal and Tesch, 1978). The resulting model was a linear equation, and therefore back-calculation of TL at age used the Fraser-Lee equation (Francis, 1990): $L_{t}=c+\left(\mathrm{TL}_{\mathrm{c}}\right.$ $-c)\left(S_{\mathrm{t}} / R\right)$, where $L_{t}$ is TL when growth mark $t$ was formed, TL $\mathrm{TL}_{\mathrm{c}}$ is TL at the time of capture, $S_{\mathrm{t}}$ is the distance from scale centre to the growth mark $t, R$ is scale radius, and $c$ is the intercept on the length axis from linear regression between TL and scale radius $\left(\mathrm{TL}=8.8449 \times R+23.588, r^{2}=0.821\right.$, $P<0.001, n=1277)$. This $c$ value was used as a fixed body-scale intercept to reduce bias due to differences in the size distribution.

Growth trajectories were compared following the procedure of Hickley and Dexter (1979) and calculated as follows: each TL at mean age $(n)$ was plotted against TL at age $(n+1)$ to obtain a straight line for the Walford (1946) method; then, TLs at age were obtained from the formula $\ln =L_{\infty}$ $\left(1-k^{n}\right)$ where: $L_{\infty}=l_{t} /(1-k), l_{t}=$ intercept on the y axis, $l n=\mathrm{TL}$ at age $n$, and $k=$ slope of the Walford plot (Hickley and Dexter, 1979). The mean TLs at age for each year class were then expressed as a proportion (\%) of the TLs from the Walford method. The proportions were summed, and the resulting mean Growth Index (GI) was used to determine relative growth for each population.

Fish condition was assessed using Fulton's condition (plumpness) factor (Mills and Eloranta, 1985: $\left.K=\mathrm{Wt} \times \mathrm{TL}^{-3} \times 10^{5}\right)$ to allow a standard comparison of crucian carp body condition between the present results and those previously published elsewhere. Mean TL and age at maturity of each population were calculated from the percentage of mature individuals in each age-class using the DeMaster (1978) formula as adapted by Fox (1994): 


$$
\begin{aligned}
& \mathrm{w} \\
& \alpha=\sum(\mathrm{x})[f(\mathrm{x})-f(\mathrm{x}-1)] \\
& \mathrm{x}=0
\end{aligned}
$$

where $\alpha$ is the mean age of maturity, $\mathrm{x}$ is the age in years, $f(\mathrm{x})$ is the proportion of fish mature at age $\mathrm{x}$, and $\mathrm{W}$ is the maximum age in the sample. A modified version of this formula $(10 \mathrm{~mm}$ TL intervals in place of age-classes) was used to calculate mean TL at maturity as per Fox and Crivelli (2001). To assess whether a relationship exists between age at maturity and juvenile growth (Fox, 1994), the former was regressed against the latter, which was defined as total length at age 2 $\left(\mathrm{TL}_{\mathrm{AGE}} 2\right)$, i.e. generally the earliest age at which female crucian carp mature. In this regression, the mid-points (ages 3.5 and 4.5) were used for the range of ages at maturity reported for Hermanninlampi Pond in Finland (Holopainen and Pitkänen, 1985) and two ponds in Russia (Dmitriyeva, 1957), with Norfolk Pond 46 excluded owing to the absence of female and male crucian carp younger than ages 6 and 5, respectively. Simple linear regressions were also used to relate growth parameters (i.e. GI and $\mathrm{TL}_{\mathrm{AGE}}$ 2) with latitude.

Male-to-female ratio was tested using the chi-squared $\left(\chi^{2}\right)$ test. Mean back-calculated TL values were analysed with one-way analysis of variance (ANOVA) for repeated measurements. Differences between GI and $K$ among populations also were tested with ANOVA. When significant differences among populations were detected, the Tukey HSD test was used to determine which populations differed. Where required, SL values were converted to TL using the conversion factor provided in FishBase (Froese and Pauly, 2013) for crucian carp $(\times 1.207)$. Finally, data for two of the Essex ponds (Earls Path, Fairmeads) are given as a single population because of an insufficient number of specimens in the individual ponds (see Tarkan et al., 2009).

Data were checked for normality and homogeneity of variances using the Shapiro-Wilk and Levene tests, respectively. If neither criterion was met, the variables were $\log _{10}$-transformed before analysis. Statistical analyses were performed with SPSS v.17 (SYSTAT Software Inc., Chicago, USA). The significance level was set at $\alpha=0.05$.

\section{RESULTS}

The extensive literature review discovered data on crucian carp from two additional water bodies in continental Europe (i.e. Poland) not reported by Tarkan et al. (2009). To complement the data for five populations in southern East Anglia (Tarkan et al., 2009), new data were collected during 2009-2012 from 20 populations (Table 1), with one data set representing a replicate in 2010 for the ornamental pond 'Bayfordbury Lake' (Hertfordshire, England), which was originally sampled in 1995 (Copp et al., 2008a). From these 20 ponds, 1456 individuals were captured, but analysis of reproductive traits and sex-ratio was possible for six of these populations only. Among the 298 fish for which sex could be determined, 158 were female and 140 were male (Table 1).

Overall sex-ratio did not differ from parity for all populations combined $\left(1: 1, \quad \chi^{2}=0.396, \quad \mathrm{df}=2\right.$, $P>0.05)$ and for the new English populations examined $\left(1: 1, \chi^{2}=1.09, \mathrm{df}=2, P>0.05\right)$; however, individually the population in Norfolk Pond 46 had a significantly higher proportion of males $\left(\chi^{2}=4.38, \mathrm{df}=2, P<0.05\right)$ and that in Norfolk Pond 40 had a significantly higher proportion of females $\left(\chi^{2}=6.54, \mathrm{df}=2, P<0.05\right)$. The smallest specimens ( $33 \mathrm{~mm}$ TL) were collected from two small ponds, Norfolk Pond 30 and Search Light Pond (Hertfordshire), and the largest (363 mm TL) was captured from Rocklands Mere, which also had the oldest specimen (13 years). The lowest maximum age (4 years) was observed in the Search Light Pond population (Table 1).

Significant differences were detected among growth (Figure 1A) of crucian populations in the three English counties $(F=4.02, P<0.05, \mathrm{df}=2$, $n=23$ ), where crucian carp populations in Norfolk grew significantly faster than those in Hertfordshire and Essex (Tukey HSD test, $P<0.05)$. English populations were comparable with those from Russia and Poland (Figure 1B), whereas those in Finland grew significantly more 
slowly ( $F=3.05, P<0.05$, df=2, $n=34)$. However, post-hoc (Tukey) comparisons indicated that the first two age classes of crucian populations in Finland achieved greater TLs than those in Russia, and those for the three English counties were significantly greater than those for the other three countries (Figure 1B).

For all sites combined, GI was inversely related to latitude $(r=-0.299 ; \quad F=22.32, \quad \mathrm{df}=38$, $P=0.022)$, but juvenile growth (TL $\left.\mathrm{TLGE}_{\mathrm{AG}}\right)$ increased in a linear fashion with increasing latitude $(r=0.346 ; F=18.5, \mathrm{df}=35, P=0.0001)$, a surrogate for temperature. Juvenile growth (Figure 1B) was significantly higher $(F=19.64$, $\mathrm{df}=35, P=0.0001)$ in crucian populations from England (mean $=82.6 \mathrm{~mm}, \mathrm{SE}=1.92, n=23$ ) than those from the Continental European countries (mean $=63.8 \mathrm{~mm}, \mathrm{SE}=4.47, n=16$ ). Similarly, GI of crucian carp was significantly higher $(F=7.26$, $\mathrm{df}=35, \quad P=0.011) \quad$ in English $\quad($ mean $=128.4$, $\mathrm{SE}=3.01, n=23)$ than in Continental European populations $($ mean $=108.9, \mathrm{SE}=7.77, n=16)$. The highest GI value was observed in Norfolk Pond 45 (1 specimen) and the minimum GI was observed in Search Light Pond, Hertfordshire (Table 1). When crucian populations were grouped by English county, which corresponds to a latitudinal gradient (Table 1) such as used in other studies of growth and life-history traits (Copp and Fox, 2007; Fox and Copp, 2014), mean GI was significantly lower $(F=4.02, \mathrm{df}=3, P<0.05)$ in Hertfordshire $(\mathrm{GI}=96)$ than in Essex $(\mathrm{GI}=103)$ and Norfolk (GI = 106) (Tukey HSD test, $P<0.05)$.

Data on condition (plumpness) factor were available from three continental water bodies (in Finland) only. Overall, the highest and lowest $K$ values were observed in England, with significant differences $(F=91.14$, df $=19, P<0.001)$ (Table 1$)$ : the pond populations in Hertfordshire had significantly lower $K$ values than most other populations (Tukey HSD test, $P<0.001$ ), and crucian carp in Essex ponds were in significantly better condition (plumper) than populations in Norfolk ponds (Tukey HSD test, $P<0.001$ ), where great variability in $K$ values was observed.

Information on length and age at maturity of crucian carp populations was relatively scarce outside of England, with value ranges given for all continental populations except one (Table 1). In England, sexual maturity was achieved later and at larger sizes in females and males from Norfolk Pond 9 and Half Oak Pond (Hertfordshire). The oldest age at sexual maturity was for males and females from Norfolk Pond 46 at ages 5 and 6, respectively. However, no fish $<135 \mathrm{~mm}$ TL were captured from this pond, and therefore the mean TLs and ages at maturity given are approximations. The youngest estimated mean age at maturity (age 2) observed in the present study was from Norfolk Pond 40 , but as no age 1 specimen was captured, the true age at maturity may be younger (Table 1). Variations in the lengths and ages at maturity $\left(\mathrm{A}_{\mathrm{M}}\right)$ for male crucian carp generally followed those of females (Table 1). There was a highly significant decrease (Figure 2; $\mathrm{A}_{\mathrm{M}}=-0.062 \times \mathrm{TL}_{\mathrm{AGE} 2}+7.296$; $\left.F=22.28, \mathrm{df}=9, r^{2}=0.712, P=0.0011\right)$ in $\mathrm{A}_{\mathrm{M}}$ of females with increasing juvenile growth $\left(\mathrm{TL}_{\mathrm{AGE}}\right)^{2}$; this relationship excludes the extreme outlier (Olsztyn Pond B) due to its 'stunted' size (Skrzydło,

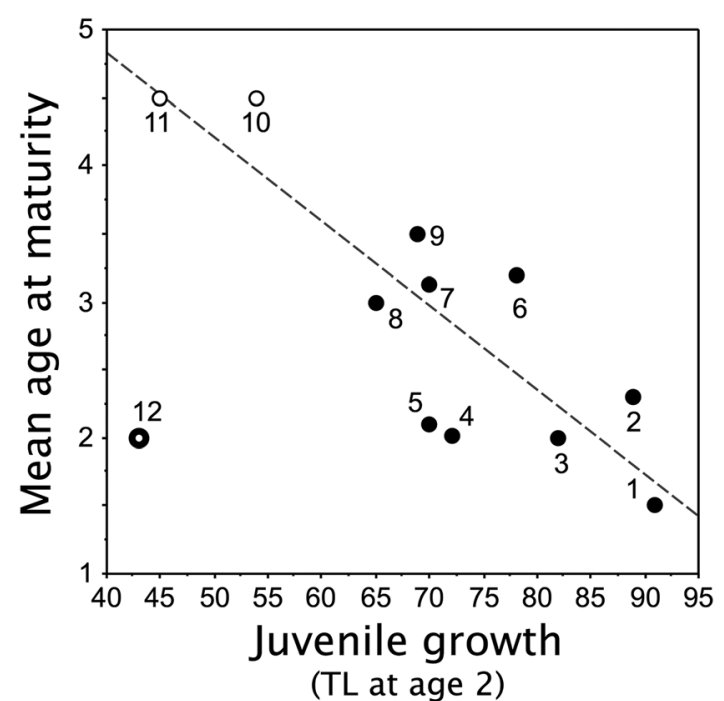

Figure 2. The significant relationship $(P=0.0011)$ between age at maturity and juvenile growth (TL $\left.\mathrm{TLGE}_{2}\right)$ for female crucian carp from pond populations in England (filled circles) and continental Europe (open circles): 1 = Earls Path/Fairmead ponds (Tarkan et al., 2009); 2 $=$ Norfolk Pond 30; 3 = Hawcock Pond (ibid.); $4=$ Norfolk Pond 40; $5=$ Pizzole Pit (ibid.); $6=$ Norfolk Pond 9; $7=$ Half Oak Pond; $8=$ Search Light Pond; 9 = Bayfordbury pond 1995 (Copp et al., 2008a, b); 10 = Lake Glubokoye/Andreyev Pond (Dmitriyeva, 1957); $11=$ Kur'kovskiy Pond (ibid.); $12=$ Olsztyn pond B (Szczerbowski et al., 1997). Sites without source citation are from the present study (Table 1). See Methods and Discussion sections (also Table 1) for exclusions from the regression analysis, i.e. Norfolk pond 46 (not shown) and Olsztyn pond B (site 12), and the assumptions regarding age at maturity values for Finnish and Russian ponds (sites 10 and 11). 
1977; Szczerbowski et al., 1997), high dominance of females (Table 1), and possible low adult survivorship - all factors associated in other fish species with populations that deviate from this relationship (see Fox, 1994).

\section{DISCUSSION}

Despite the long tradition of angling for crucian carp in the UK and the species' threatened status in England (Sayer et al., 2011), very limited information was available on the species' demography (Marlborough, 1967) until recently (Copp et al., 2008a, b; Tarkan et al., 2009, 2011). The present review reveals that crucian carp growth and reproductive traits vary considerably in all European countries for which data are available (Table 1, Figure 1), with specimens up to $3 \mathrm{~kg}$ weight apparently present in the eastern part of the Baltic Sea (Anonymous, pers. comm.). Such variation is a common feature of widely distributed fish species (Mann, 1991), and growth variations in crucian carp generally reflect different environmental conditions, e.g. pond size, temperature, predation pressure, food availability or quality and competition (Holopainen et al., 1988; Szczerbowski et al., 1997), although this wide plasticity warrants further investigation. Among European crucian populations, early growth was slowest in Russia and fastest in England, whereas growth in later life was fastest in Russia and slowest in Finland (Figure 1).

Temperature-dependent variations in the growth of fishes, including crucian carp (Tarkan et al., 2011), are often the result of a non-linear relationship with water temperature (Lappalainen et al., 2008). Despite an initial near-linear increase with temperature, growth rate has been demonstrated to reach an optimum and then decline rapidly until it finally ceases (Elliott, 1975). Species at the extreme limits of their native distribution are considered to persist in sub-optimal conditions and, therefore, are more susceptible to environmental stressors (Noble et al., 2007). However, the relatively benign climate of England appears to buffer this effect, facilitating good overall growth in crucian carp. Indeed, juvenile growth increased linearly with decreasing latitude, a surrogate for temperature, such as reported for other temperate fish species, e.g. roach Rutilus rutilus (Cyprinidae) (Kubecka, 1994). Nevertheless, temperature is unlikely to be the primary reason for the observed growth variations, given the proximity of the ponds and thus similar temperature regimes (Tarkan et al., 2009; Copp et al., 2010). A long-term study on growth pattern variations of crucian carp in relation to environmental factors from an ornamental pond (Bayfordbury) in England revealed that density-dependent growth in crucian carp may be as important as density-independent growth (Tarkan et al., 2011).

Growth plasticity in crucian carp may be linked to inter- or intra-specific competition where available food resources are inadequate (Holopainen et al., 1997). However, inter-specific competition was not found to be important in crucian carp populations living with and without a non-native congeneric species (e.g. goldfish $C$. auratus), and this was attributed to maximization of its potential somatic growth when confronted with the congener (Tarkan et al., 2009). Crucian carp co-exists with goldfish in two of the populations of the present study (Norfolk Pond 9; Strawberry Hill Pond, Essex), but the crucian carp populations in both these ponds had very different relative growth patterns, most likely owing to differences in fish density - the high density population in Norfolk Pond 9 demonstrated the slowest growth observed in the present study (see also Tarkan et al., 2011), whereas the low-density re-introduced population in Strawberry Hill Pond had the fastest growth. Other factors such as competitive interactions, predation (including cannibalism) or environmental drivers (e.g. changes in water quality) can affect the growth, longevity and abundance of crucian carp populations (Tarkan et al., 2011; Lappalainen et al., 2013). This can be seen in the dramatic changes in life-span and age-specific growth of crucian carp in the ornamental pond at Bayfordbury. This population, sampled in 1995 just before the onset of annual visits by great cormorants to prey on fish in the pond (Copp et al., 2008b), was longer lived, slower growing and at a higher density than in 
2010, when fish at age 6 achieved a longer mean TL than did age 10 fish from the 1995 sample. This suggests that variable growth rates may lead to different life-spans in fish populations, such as observed in some other native cyprinids with wide distributions, e.g. roach (Lappalainen et al., 2008); however, no correlation was observed in the present study between growth index and life-span.

Age at maturity of both sexes of crucian carp varied greatly in England and in continental Europe, although most populations matured between ages 2 and 3. The influence of juvenile growth on age at maturity, which decreases with increasing juvenile growth (Figure 2), is a similar relationship to that reported for several other fish species in which it has been shown to vary according to population density (Goto, 1993), co-existence with a congeneric competitor (Fox 1994), geographical clines (Mann et al., 1984) and invasiveness potential (Copp and Fox, 2007). In the case of crucian carp (Figure 2), the main factor underlying this relationship appears to be climatic, given the significant decrease in juvenile growth with increasing latitude and the significantly faster juvenile growth in English populations relative to those from continental Europe (see Results). However, some other factor (possibly high intra-specific competition for spawning partners) was acting on crucian carp in Olsztyn pond B (Poland), which contained no other fish species (A. Szczerbowski, personal communication) - its crucian population had the slowest juvenile growth among those included in the regression analysis (Figure 2) but a reported age at maturity of 2 years. Slow-growing, early maturing females have been observed in other freshwater fishes (Alm, 1946; Leggett and Power, 1969), including both native and non-native populations of 'stunted' pumpkinseed in which low adult survival was observed (Fox, 1994). The stunted form in crucian carp has been linked to high density mono-specific populations (Piironen and Holopainen, 1988) due to limited food resources (Penttinen and Holopainen, 1992). This appears to explain the slow juvenile growth and earlier maturation of the stunted population in Olsztyn pond B (Figure 2; Szczerbowski et al., 1997), which is also strongly dominated by females (Table 1).
This relatively young age at maturity ( 2 years) has also been reported for non-native crucian carp populations established in two Turkish reservoirs, the most southern latitudes for this species (Becer et al., 1998). This contrasts with other species (Hutchings, 1993; Fox, 1994; Tarkan, 2006), as well as life-history theory (Atkinson, 1994), which predicts that ectotherms will exhibit faster juvenile growth, precocious maturity, and shorter life-spans in response to elevated water temperatures. Using latitude as a surrogate of water temperature, the present results showed significant relationships with growth indices (overall growth index and juvenile growth) but not with reproductive indicators. Assuming that crucian carp are native to England, there are limited data for introduced populations of this species. The only such study known is that of Becer et al. (1998) in which reported juvenile growth ( $\left.\mathrm{TL}_{\mathrm{AGE}}{ }_{2}\right)$ was $229 \mathrm{~mm}$ TL. However, given that no crucian carp population achieves such a body length until at least age 6, and Becer et al. (1998) did not describe an age validation protocol, the growth of crucian carp in southern areas such as Turkey requires further study to confirm or refute the excessively fast juvenile growth reported by Becer et al. (1998).

\section{CONCLUSIONS}

Growth, body condition and life-history traits were highly variable, both within and between crucian carp populations in the East of England and continental Europe. Yet, as pointed out previously (Tarkan et al., 2009), the growth indicators suggest that crucian carp benefits from the relatively benign climate of England despite this being at the western extent of the species' European range. This is further emphasized in the significant relationship between age at maturity and juvenile growth, whereby English populations are generally characterized by faster juvenile growth and earlier maturity than their continental counterparts, with the exception of 'stunted' populations (Figure 2). Future climate change scenarios predict mean water temperature increases of $2-3{ }^{\circ} \mathrm{C}$ for southern England (Hulme et al., 2002; Jenkins et al., 2009), which may provide the same growth benefits to crucian carp 
as predicted for its close non-native congeners, goldfish and gibel carp, and also for introduced common carp Cyprinus carpio (Britton et al., 2010). The warmer conditions may exacerbate the potential density-dependent impacts of these related non-native fishes, which are already suspected of strongly competing and genetically contaminating crucian carp populations (Hänfling et al., 2005; Papoušek et al., 2008), such as has been reported for Sweden (Wouters et al., 2012).

Given the considerable declines (by $\approx 75 \%$ ) in the numbers of crucian carp populations through changes in land use and non-native species introductions (Sayer et al., 2011), conservation efforts should focus on improving the environmental conditions in ponds where body condition, reproduction and growth rates are low. For this purpose, different measures of habitat restoration could be implemented such as avoiding pond 'terrestrialization' (e.g. colmatation, excessive shade by vegetation cover), eutrophication by controlling pollution from agricultural activities or promoting high diversity of both riparian and aquatic vegetation to increase food supply as benthic invertebrate biomass. Beside this, ponds containing crucian carp populations in good status should be monitored to maintain those particular environmental conditions. Indeed, these ponds may serve as 'source areas' for future re-stocking of rehabilitated ponds. Moreover, fish densities could be reduced by removing non-native species, specifically goldfish and common carp. This will reduce the risks of potential interspecific competition (Copp and Sayer, 2010; Sayer et al., 2011), as well as of genetic introgression due to hybridization (Hänfling et al., 2005). In particular, if populations of non-native fishes can be reduced and measures of habitat restoration implemented in ponds, then England represents an ideal geographic area for conservation of crucian carp within a European context.

\section{ACKNOWLEDGEMENTS}

This study was funded by the British Council (grant to A.S. Tarkan), by Cefas through support from the UK Department of Environment, Food and Rural Affairs (Defra), by the Norfolk Biodiversity
Partnership, and by the UK Environment Agency (D. Almeida). We are grateful to K. J. Wesley, D. Emson and I. Patmore for assistance in the field, to N. Top (Muğla Sitkı Koçman University) for assistance with the fish ageing, and to an anonymous reviewer for information on the maximum weight recorded for crucian carp in the eastern Baltic. Thanks are due to the many landowners who gave authors access to their lands and ponds, and to J. Zdanowska and A. Szczerbowski for unpublished information on the fish composition of Olsztyn ponds.

\section{REFERENCES}

Alm G. 1946. Reasons for the occurrence of stunted fish populations with special regard to the perch. Report of the Institute of Freshwater Research Drottningholm 25: $1-146$.

Almeida D, Rodolfo N, Sayer CD, Copp GH. 2013. Seasonal use of ponds as foraging habitat by Eurasian otter with description of an alternative handling technique for common toad predation. Folia Zoologica 62: 214-221.

Atkinson D. 1994. Temperature and organism size - a biological law for ectotherms. Advances in Ecological Research 25: 1-58.

Bagenal TB, Tesch FW, 1978. Age and growth. In Methods for Assessment of Fish Production in Fresh Waters, Bagenal TB (ed). Blackwell Scientific: Oxford; 101-136.

Becer ZA, Kır İ, Çubuk H. 1998. Some reproductive characteristics of Carassius carassius L., 1758 (Isparta-Burdur) in the Karacaören-I Dam Lake (in Turkish). In XIV National Biology Congress 7-10 September, Samsun: Turkey; 126-138.

Białokoz W. 1977. The effect of selected individual and population traits on absolute and relative fecundity of bream (Abramis brama L.), crucian carp (Carassius carassius L.) and guppy (Lebistes reticulates Peters) [Wpływ Wybranych cech Osobniczych i Populacyjnych na Płodność Absolutną i Względną Leszcza (Abramis brama L.), Karasia (Carassius carassius L.) i Gupika (Lebistes reticulates Peters)]. MSc thesis, University of Agriculture and Technology, Olsztyn: Poland.

Britton JR, Cucherousset J, Davies GD, Godard MJ, Copp GH. 2010. Non-native fishes and climate change: predicting species responses to warming temperatures in a temperate region. Freshwater Biology 55: 1130-1141.

Ciepielewski W. 1967. Growth and survival of an isolated population of crucian carp (Carassius carassius) in a small unexploited lake. Roczniki Nauk Rolniczych Seria $H$ Zootechniczna 90: 239-248. (In Polish).

Conservators of Epping Forest. 2002. Epping Forest Annual Report of the Superintendent for 2001/2002, Corporation of London: Loughton, Essex.

Copp GH, Fox MG. 2007. Growth and life history traits of introduced pumpkinseed (Lepomis gibbosus) in Europe, and the relevance to invasiveness potential. In Freshwater 
Bioinvaders: Profiles, Distribution, and Threats, Gherardi F (ed). Springer: Berlin; 289-306.

Copp GH, Sayer CD. 2010. Norfolk Biodiversity Action Plan - local species Action Plan for Crucian Carp (Carassius carassius). Norfolk Biodiversity Partnership Reference: LS/3. Centre for Environment, Fisheries and Aquaculture Science: Lowestoft. Available from: (http:// www.cefas.defra.gov.uk/publications-and-data/miscellaneouspublications.aspx). [2 December 2013]

Copp GH, Wesley KJ, Vilizzi L. 2005. Pathways of ornamental and aquarium fish introductions into urban ponds of Epping Forest (London, England): the human vector. Journal of Applied Ichthyology 21: 263-274.

Copp GH, Černý J, Kováč V. 2008a. Growth and morphology of an endangered native freshwater fish, crucian carp Carassius carassius, in an English ornamental pond. Aquatic Conservation: Marine Freshwater Ecosystems 18: 32-43.

Copp GH, Warrington S, Wesley KJ. 2008b. Management of an ornamental pond as a conservation site for a threatened native fish species, crucian carp Carassius carassius. Hydrobiologia 597: 149-155.

Copp GH, Tarkan AS, Godard MJ, Edmonds NJ, Wesley KJ. 2010. Preliminary assessment of feral goldfish impacts on ponds, with particular reference to native crucian carp. Aquatic Invasions 5: 413-422.

Deinhardt M. 2013. The invasive potential of Prussian carp in Finland under the light of a novel semi-clonal reproductive mechanism. Master of Science Thesis, University of Jyväskylä: Finland, 73 pp. (Available from: https://jyx. jyu.fi/dspace/bitstream/handle/123456789/42466/URN:NBN: fi:jyu-201311152601.pdf?sequence=1) (last accessed: 22-04-2015)

DeMaster DP. 1978. Calculation of the average age of sexual maturity in marine mammals. Journal of Fisheries Research Board of Canada 35: 912-915.

Dmitriyeva EN. 1957. Morphological and ecological analysis of two species of crucian carp. Trudy Instituta Morfologii Zhivotnykh AN Severtsova 16: 102-170.

Elliott JM. 1975. The growth rate of brown trout (Salmo trutta L.) fed on maximum rations. Journal of Animal Ecology 44: 805-821.

Fox MG. 1994. Growth, density, and interspecific influences on pumpkinseed sunfish life histories. Ecology 75: 1157-1171.

Fox MG, Copp GH. 2014. Old world vs new world - life history alterations in a successful invader introduced across Europe. Oecologia 174: 435-446.

Fox MG, Crivelli AJ. 2001. Life history traits of pumpkinseed (Lepomis gibbosus) populations introduced into warm thermal environments. Archiv für Hydrobiologie 150: 561-580.

Francis RICC. 1990. Back-calculation of fish length: a critical review. Journal of Fish Biology 36: 883-902.

Froese R. 2006. Cube law, condition factor and weight-length relationships: history, meta-analysis and recommendations. Journal of Applied Ichthyology 22: 241-253.

Froese R, Pauly D. 2013. FishBase. World Wide Web electronic publication. (Available from: http://www. fishbase.org/) [2 December 2013]

Goto A. 1993. Clinal life-history variation in the river-sculpin, Cottus hangiongensis: an example of phenotypic plasticity. Japanese Journal of Ichthyology 39: 363-370.

Hänfling B, Bolton P, Harley M, Carvalho GR. 2005. A molecular approach to detect hybridisation between crucian carp (Carassius carassius) and non indigenous carp species (Carassius spp. and Cyprinus carpio). Freshwater Biology 50: 403-417.

Hickley P, Dexter FK. 1979. A comparative index of quantifying growth in length of fish. Aquaculture Research 10: $147-151$.

Holopainen IJ, Ikari A. 1992. Ecophysiological effects of temporary acidification on crucian carp, Carassius carassius (L.): a case history of a forest pond in eastern Finland. Annales Zoologici Fennici 29: 29-38.

Holopainen IJ, Pitkänen AK. 1985. Population size and structure of crucian carp (Carassius carassius (L.)) in two small natural ponds in Finland. Annales Zoologici Fennici 22: 397-406.

Holopainen IJ, Tonn WM, Paszkowski CA, Pitkanen AK. 1988. Habitat use, diel activity, and growth of crucian carp in a manipulated pond. Verhandlungen Internationalen Vereinigung für theoretische und angewandte Limnologie 21: $1743-1750$.

Holopainen IJ, Tonn WM, Paszkowski CA. 1997. Tales of two fish: the dichotomous biology of crucian carp (Carassius carassius (L.)) in northern Europe. Annales Zoologici Fennici 34: 1-22.

Hulme M, Lu X, Turnpenny J, Mitchell T, Jenkins G, Jones R, Lowe J, Murphy J, Hassel D, Boorman P, et al. 2002. Climate change scenarios for the United Kingdom: the UKCIP02 Scientific Report. Tyndall Centre for Climate Change Research, University of East Anglia: Norwich.

Hutchings JA. 1993. Adaptive life histories affected by age-specific survival and growth-rate. Ecology 74: 673-684.

Jenkins GJ, Murphy JM, Sexton DMH, Lowe JA, Jones P, Kilsby CG. 2009. UK Climate Projections: Briefing report, Met Office Hadley Centre: Exeter.

Jones AKG. 1978. A note on the fish remains. In Southwark Excavations 1972-1974, Bird J, Graham AH, Sheldon H, Townend P. (eds). Southwark and Lambeth Archaeological excavation committee. Joint Publication No 1. The London and Middlesex Archaeological Society with the Surrey Archaeological Society: London; 601-602.

Keresztessy K, Farkas J, Sevcsik A, Tóth B, Vad CF, Weiperth A. 2013. Effects of habitat rehabilitation on the fish fauna of the Öreg-turján peatland at Ócsa. Pisces Hungarici 7: 37-43. (In Hungarian with English abstract).

Kubecka J. 1994. Models for comparing average first year growth in length of freshwater fish. Fisheries Management and Ecology 1: 45-55.

Lappalainen J, Tarkan AS, Harrod C. 2008. A meta-analysis of latitudinal variations in life history traits of roach Rutilus rutilus over its geographical range: linear or non-linear relationships? Freshwater Biology 53: 1491-1501.

Lappalainen J, Vinni M, Malinen T. 2013. Consumption of crucian carp (Carassius carassius L., 1758) by restocked pike (Esox lucius L., 1758) in a lake with frequent winter hypoxia. Journal of Applied Ichthyology 29: 1286-1291.

Leggett WC, Power G. 1969. Differences between two populations of landlocked Atlantic salmon (Salmo salar) in Newfoundland. Journal of the Fisheries Research Board of Canada 26: 1585-1596.

Maitland PS. 2004. Keys to the freshwater fish of Great Britain and Ireland with notes on their distribution and ecology. Scientific Publication No. 62, Freshwater Biological Association: Ambleside, Cumbria. 
Mann RHK. 1991. Growth and production. In Cyprinid Fishes. Systematics, Biology and Exploitation, Winfield IJ, Nelson JS (eds). Chapman and Hall: London; 446-481.

Mann RHK, Mills CA, Crisp DT. 1984. Geographical variation in the life-history tactics of some species of freshwater fish. In Fish Reproduction. Strategies and Tactics, Potts GW, Wootton RJ (eds). Academic Press: London; 171-186.

Marlborough D. 1966. The reported distribution of the crucian carp in Britain, 1954 to 1962. The Naturalist 1966: 1-3.

Marlborough D. 1967. Some studies on common carp (Cyprinus carpio L.) and crucian carp (Carassius carassius L.) in a small Middlesex pond. The London Naturalist 46: 76-81.

Mills CA, Eloranta A. 1985. The biology of Phoxinus phoxinus (L.) and other littoral zone fishes in Lake Konnevesi, central Finland. Annales Zoologica Fennici 22: 1-12.

Navodaru I, Buijse AD, Staras M. 2002. Effects of hydrology and water quality on the fish community in Danube delta lakes. International Review of Hydrobiology 87: 329-348.

Newdick J. 1979. The Complete Freshwater Fishes of the British Isles, A \& C Black (Publishers) Ltd: London.

Noble RAA, Cowx IG, Goffaux D, Kestemont P. 2007. Assessing the health of European rivers using functional ecological guilds of fish communities: standardizing species classification and approaches to metric selection. Fisheries Management and Ecology 14: 381-392.

Oertli B, Biggs J, Céréghino R, Grillas P, Joly P, Lachavanne JB. 2005. Conservation and monitoring of pond biodiversity: introduction. Aquatic Conservation: Marine Freshwater Ecosystems 15: 535-540.

Papoušek I, Vetešník L, Halačka K, Lusková V, Humpl M, Mendel J. 2008. Identification of natural hybrids of gibel carp Carassius auratus gibelio (Bloch) and crucian carp Carassius carassius (L.) from lower Dyje River floodplain (Czech Republic). Journal of Fish Biology 72: 1230-1235.

Penttinen OP, Holopainen IJ. 1992. Seasonal feeding activity and ontogenetic dietary shifts in crucian carp, Carassius carassius. Environmental Biology of Fishes 33: 215-221.

Piironen J, Holopainen IJ. 1988. Length structure and reproductive potential of crucian carp (Carassius carassius (L.)) populations in some forest ponds. Annales Zoologica Fennici 25: 203-208.

Rannap R, Lohmus A, Briggs L. 2009. Restoring ponds for amphibians: a success story. Hydrobiologia 634: 87-95.

Sayer CD, Copp GH, Emson D, Godard MJ, Zięba G, Wesley K. 2011. Towards the conservation of crucian carp Carassius carassius: understanding the extent and causes of decline within part of its native English range. Journal of Fish Biology 79: 1608-1624.

Schwevers U, Adam B, Gumpinger C. 1999. Zur Bedeutung von Auegewässern für die Fischfauna von Bundeswasserstraßen. Wasser und Boden 51: 35-39.

Skrzydło A. 1977. Chemical, Food and Ichthyological Characteristics of Disappearing Reservoir in Stary Dwór
Forest District [Charakterystyka Chemizmu, Warunków Pokarmowych $i$ Ichtiofauny Zanikajacego Zbiornika Śródleśnego w Leśnictwie Stary Dwór]. MSc thesis, University of Agriculture and Technology: Olsztyn, Poland.

Steiner E. 1988. Teichwirtschaft und Naturschutz. Österreichs Fisherei 41: 142-149. (English summary)

Steinmetz B, Müller R. 1991. An Atlas of Fish Scales, and Other Body Structures used for Age Determination: Non-Salmonid Species Found in European Fresh Waters, Samara Publishing: Cardigan.

Szczerbowski A, Zakęś Z, Łuczyński MJ, Szkudlarek M. 1997. Maturation and growth of a stunted form of crucian carp Carassius carassius (L.) in natural and controlled conditions. Polskie Archiwum Hydrobiologii 44: 171-180.

Tarkan AS. 2006. Reproductive ecology of two cyprinid fishes in an oligotrophic lake near the southern limits of their distribution range. Ecology of Freshwater Fish 15: 131-138.

Tarkan AS, Copp GH, Zięba G, Godard MJ, Cucherousset J. 2009. Growth and reproduction of threatened native crucian carp Carassius carassius in small ponds of Epping Forest, south-east England. Aquatic Conservation: Marine Freshwater Ecosystems 19: 797-805.

Tarkan AS, Gaygusuz Ö, Godard MJ, Copp GH. 2011. Long-term growth patterns in a pond-dwelling population of crucian carp, Carassius carassius: environmental and density-related factors. Fisheries Management Ecology 18: $375-383$.

Vetemaa M, Eschbaum R, Albert A, Saat T. 2005. Distribution, sex ratio and growth of Carassius gibelio (Bloch) in coastal waters of Estonia (eastern Baltic Sea). Journal of Applied Ichthyology 21: 287-291.

Vilizzi L, Copp GH, Britton JR. 2013. Age and growth of European barbel Barbus barbus (Cyprinidae) in the small, mesotrophic River Lee and relative to other populations in England. Knowledge and Management of Aquatic Ecosystems 409: 09.

Walford LA. 1946. A new graphic method of describing the growth of animals. Biological Bulletin of the Marine Biology Laboratory, Woods Hole 90: 141-147.

Wheeler AC. 2000. Status of the crucian carp, Carassius carassius (L.), in the UK. Fisheries Management and Ecology 7: 315-322.

Williams P, Whitfield M, Biggs J, Bray S, Fox G, Nicolet P, Sear D. 2003. Comparative biodiversity of rivers, streams, ditches and ponds in an agricultural landscape in Southern England. Conservation Biology 115: 329-341.

Wouters J, Janson S, Lusková V, Olsén KH. 2012. Molecular identification of hybrids of the invasive gibel carp Carassius auratus gibelio and crucian carp Carassius carassius in Swedish waters. Journal of Fish Biology 80: 2595-2604.

Zawisza J, Antosiak B. 1961. The rate of growth of crucian carp (Carassius carassius L.) in lakes of Węgorzewo district. Roczniki Nauk Rolniczych Seria B Zootechniczna 77: 527-548. (In Polish). 